\title{
Dehydrated cassava co-product in starting piglets feeding
}

\section{Coproduto desidratado de mandioca na alimentação de leitões na fase inicial}

\author{
Davi Elias de Sá e Castro'; Paulo Levi de Oliveira Carvalho ${ }^{*}$; Newton Tavares \\ Escocard de Oliveira'; ${ }^{2}$ Ricardo Vianna Nunes'; Jansller Luiz Genova ${ }^{3}$; \\ Vanja de Souza Rocha'; Ana Lúcia Almeida Santana ${ }^{5}$ Aparecida da Costa \\ Oliveira $^{6}$; Silvana Teixeira Carvalho ${ }^{2}$
}

\begin{abstract}
Two experiments were carried out to determine the nutritional value of a dehydrated cassava co-product (DCC) and its effects on the performance and blood variables of piglets fed with different levels of DCC. In experiment I, a digestibility assay was performed and 30 whole-male crossbred piglets with initial body weight of $18.00 \pm 0.673 \mathrm{~kg}$ were housed individually in metabolism cages and distributed in a completely randomized experimental design with 5 treatments, 6 replicates and one animal per experimental unit. A reference diet was formulated to meet the category nutritional requirements and the different levels of DCC replacement $(6,12,18$ and $24 \%)$ were used to replace the reference diet and composed the treatments. In experiment II, 120 piglets (60 whole males and 60 females) were used, with initial body weight of $13.05 \pm 1.59 \mathrm{~kg}$, distributed in a randomized complete block design with 5 treatments, 6 replicates and 4 animals per experimental unit. Treatments consisted of five feeds with increasing inclusion levels $(0,3,6,9$ and $12 \%)$ of the DCC. The feed based on corn and soybean meal were formulated to meet the recommended levels in starting piglets feeding. The data were submitted for statistical analysis and, when presenting significant difference, the averages were compared by the Dunnet's test at $10 \%$ significance. In the digestibility assay, the values of DCC's digestive energy and metabolizable energy of 3,022 and 2,984 kcal kg ${ }^{-1}$ in natural matter, respectively, were found. There was no significant effect ( $p>0.10)$ of inclusion levels of DCC on the final weight and daily gain of weight however we observed a quadratic effect $(\mathrm{p}<0.10)$ of the DCC levels on daily feed intake and feed conversion. For the analysis of blood parameters, the results showed that there was no effect $(p>$ 0.10 ) of DCC levels on glucose and blood urea in the different treatments. The use of the dehydrated cassava co-product can be an energetic alternative to piglets in starting phase and can be used up to $12 \%$.
\end{abstract}

Key words: Alternative food. Nutrition. Swine production.

\footnotetext{
${ }^{1}$ Discente de Mestrado, Programa de Pós-Graduação em Zootecnia, Universidade Estadual do Paraná, UNIOESTE, Marechal Cândido Rondon, PR, Brasil. E-mail: davi_sa30@hotmail.com

2 Profs. Drs., Curso de Zootecnia, UNIOESTE, Marechal Cândido Rondon, PR, Brasil. E-mail: paulolevi@yahoo.com.br; newtonescocard@hotmail.com; nunesrv@hotmail.com; silteixeira@gmail.com

3 Discente de Doutorado, Programa de Pós-Graduação em Zootecnia, UNIOESTE, Marechal Cândido Rondon, PR, Brasil. E-mail: jansllerg@gmail.com

4 Zootecnista, Universidade Federal de Alagoas, UFAL, Maceió, AL, Brasil. E-mail: vanjazootecnista@gmail.com

5 Pós-Doutoranda em Ciência Animal, Universidade Federal do Recôncavo da Bahia, UFRB, Cruz das Almas, BA, Brasil. E-mail: ninhaemarc@hotmail.com

6 Pós-Doutoranda em Zootecnia, UNIOESTE, Marechal Cândido Rondon, PR, Brasil. E-mail: aparecidacostaoliveira@gmail.com

* Author for correspondence
}

Received: Nov. 30, 2016 Approved: May 19, 2017 


\section{Resumo}

Dois experimentos foram conduzidos, objetivando-se determinar o valor nutricional do Coproduto Desidratado de Mandioca (CDM) e seus efeitos no desempenho e nas variáveis sanguíneas de leitões alimentados com diferentes níveis do CDM. No experimento I, realizou-se um ensaio de digestibilidade e foram utilizados 30 leitões híbridos, machos inteiros, com peso vivo inicial de 18,00 $\pm 0,673 \mathrm{~kg}$, alojados individualmente em gaiolas de metabolismo, e distribuídos em um delineamento experimental inteiramente casualizado, com 5 tratamentos, 6 repetições e um animal por unidade experimental. Uma ração referência foi formulada para atender as exigências nutricionais da categoria e diferentes níveis de substituição do $\operatorname{CDM}(6,12,18$ e 24\%) foram utilizados para substituir a ração referência, compondo os tratamentos. No experimento II, foram utilizados 120 leitões (60 machos inteiros e 60 fêmeas), com peso vivo inicial de 13,05 $\pm 1,59 \mathrm{~kg}$, distribuídos em um delineamento experimental em blocos casualizados, com 5 tratamentos, 6 repetições e 4 animais por unidade experimental. Os tratamentos consistiram de cinco rações com níveis crescentes de inclusão $(0,3,6,9$ e 12\%) do CDM. As rações à base de milho e farelo de soja foram formuladas para atender ao recomendado para suínos na fase inicial. Os dados foram submetidos à análise estatística e, ao apresentar diferença significativa, as médias foram comparadas pelo teste de Dunnet a $10 \%$ de significância. No ensaio de digestibilidade, foram encontrados os valores de Energia Digestível e Energia Metabolizável do CDM de 3022 e 2984 $\mathrm{kcal} \mathrm{kg}^{-1}$ na matéria natural, respectivamente. Não houve efeito $(\mathrm{P}>0,10)$ de níveis de inclusão de $\mathrm{CDM}$ sobre o peso final e ganho diário de peso, no entanto observou-se efeito quadrático $(\mathrm{P}<0,10)$ dos níveis de CDM sobre o consumo diário de ração e conversão alimentar. Para as análises dos parâmetros sanguíneos, os resultados mostraram que não houve efeito $(\mathrm{P}>0,10)$ de níveis de CDM sobre a glicose e a ureia sanguínea nos diferentes tratamentos. $\mathrm{O}$ uso do coproduto desidratado de mandioca pode ser uma alternativa energética para rações de leitões na fase inicial, podendo ser utilizado até o nível de $12 \%$.

Palavras-chave: Alimentos alternativos. Nutrição. Suinocultura.

\section{Introduction}

The total cost of production in production swine can vary depending on the season in stable and full cycle farms. In general, around $65 \%$ of the total production costs are focused on food while in the off season, the cost for food can increase to $70 \%$ to $75 \%$. Since, it is important to search for available ingredients, both in quantity and quality, at affordable prices, to make production feasible (ALBUQUERQUE et al., 2011).

While corn is equivalent to approximately $65 \%$ of the volume of commercial feed for pigs, alternatives are being considered as the main energy source of swine feed. This change would favor both the producer and the consumer. In this context, cassava (Manihot esculenta C.), an agricultural crop in Brazil, could become a viable option and be used in animal feed in the "in natura" way or through the co-products of its processing, such as the dehydrated cassava co-product (FERREIRA et al., 2014).

The dehydrated cassava co-product, or solid starch residue, consists of fibrous material and starch not extracted during cassava processing, and has approximately 60 to $70 \%$ starch, $1.7 \%$ crude protein, $11 \%$ crude fiber (PICOLI et al., 2014). When not used in animal nutrition or for the production of biodegradable organic compounds, the cassava processing residue is deposited in the environment, becoming a polluting agent (SOUSA et al., 2012).

For each ton of processed root, about 250 $\mathrm{kg}$ of cassava starch and $928.6 \mathrm{~kg}$ of bagasse are produced (FIORDA et al., 2013). The cassava starch production Industry in Brazil, generate 2.09 million tons of these wet residues a year (IBGE, 2015). As a result the dehydrated cassava co-product is being considered as an animal nutrition alternative due to 
the large amount of residue which is produced and the percentage in starch available within it.

However, there is little scientific information available on the use of dehydrated cassava coproduct (DCC) in swine feed, which justifies the need for this study. In addition, this ingredient can become an important alternative energy source to corn. In this context, the objective of this work was to determine the nutritional value and the performance and blood parameters of pigs in starting phase fed with DCC.

\section{Material and Methods}

Two experiments were carried out in the Swine Sector of the Experimental Station Nucleus of the Universidade Estadual do Oeste do Paraná, Campus of Marechal Cândido Rondon PR, located in Linha Guará. The first experiment was to determine the nutrient and energy digestibility coefficients of the metabolizable energy of dehydrated cassava coproduct (DCC), and the second experiment was to evaluate the pigs' performance and blood parameters of piglets. All procedures involving the animals were approved by CEUA/UNIOESTE, under the protocol number $39 / 15$, being in compliance with the Brazilian guidelines for the care and handling of animals used for scientific purposes.

The dehydrated cassava co-product (DCC) was obtained in the Amafil starch industry, located in the municipality of Altônia - Paraná, after drying under pressure of $9 \mathrm{~kg} \mathrm{~h}^{-1}$ for 15 to 20 minutes. A sample of the material was sent to the UNIOESTE's Animal Nutrition Laboratory, where the levels of dry matter (DM), organic matter (OM), mineral matter (MM), ethereal extract (EE), crude energy (CE), crude protein (CP), acid detergent fiber (ADF) and neutral detergent fiber (NDF) were analyzed according to the methodologies described by Silva and Queiroz (2002). Briefly, an amino-amylase and amyloglucosidase enzyme digestions were used, followed by UV-VIS $520 \mathrm{~nm}$ spectrophotometer (AOAC, 1990). The starch analysis was performed in the Fundação ABC laboratory, following the enzymatic method.

\section{Experiment 1- Digestibility assay}

In Experiment 1, the digestibility assay included 30 whole-breed crossbred piglets with an initial weight of $18.00 \pm 0.673 \mathrm{~kg}$ used in a completely randomized experimental design, with five treatments, six replicates and one animal per experimental unit. The animals were housed individually in metabolism cages similar to those described by Pekas (1968), where they remained for 12 days, seven for adaptation to cages and feed, and five days for collection of feces and urine.

A reference feed (Table 1) based on corn and soybean meal was formulated to meet the requirements established by Rostagno et al. (2011), for barrows of high genetic potential with superior performance, with live weight in the range of 15 to $30 \mathrm{~kg}$. The treatments consisted of five increasing levels of substitution of the reference diet by DCC $(6,12,18$ and $24 \%)$.

The procedures for diets, feces and urine collection were according to the methods described by Sakomura and Rostagno (2016). The animals received two daily meals, provided in the morning at 8:00am and in the afternoon at 3:00 p.m., and the total daily amount in the collection period determined from the adaptation period, based on the animals' voluntary consumption and metabolic weight (PV0.75). The feed was moistened with $20 \%$ water to avoid waste, reduce powderyness and to improve animal acceptability. After each meal, water was fed through the feeder in the proportion of $3 \mathrm{~mL} \mathrm{~g}^{-1}$ of feed consumed, and calculated for each experimental unit, to avoid excess water consumption.

During the collection period, $1 \%$ of ferric oxide $\left(\mathrm{Fe}_{2} \mathrm{O}_{3}\right)$ was added to the feed to mark the beginning and end of fecal collection. In the collection period, the feces produced daily were weighed and 
conditioned in previously identified plastic bags and stored in a freezer at $-18^{\circ} \mathrm{C}$. After the collection period, they were thawed, homogenized and a composite sample of $20 \%$ of each experimental unit was removed, dried in a forced ventilation oven $\left(55^{\circ} \mathrm{C}\right)$, ground in a Wiley type grinder mill and stored in polyethylene pots for total carbohydrates (TC), non-fibrous carbohydrates (NFC), DM, MM, $\mathrm{CP}, \mathrm{NDF}, \mathrm{ADF}, \mathrm{EE}$ and $\mathrm{CE}$, were carried out at the Unioeste's Animal Nutrition Laboratory (LANA/ Unioeste).

Table 1. Centesimal and bromatological composition of the reference diet in the piglet metabolism test in starting phase.

\begin{tabular}{lc}
\hline Ingredients (\%) & Amount \\
\hline Corn & 66.610 \\
Soybean meal (45\%) & 28.718 \\
Monodicalcium phosphate & 1.369 \\
Soy oil & 1.107 \\
Limestone & 1.062 \\
Lysine sulfate $(50.7 \%)$ & 0.420 \\
Common salt & 0.400 \\
Mineral Premix ${ }^{1}$ & 0.100 \\
Vitaminic Premix ${ }^{2}$ & 0.050 \\
DL-methionine (85\%) & 0.089 \\
L-threonine (99\%) & 0.075 \\
\hline Total & 100.00 \\
\hline & \\
\hline Metabolizable Energy, kcal/kg & 3.230 \\
Crude Protein, \% & 18.345 \\
Digestive Lysine, \% & 1.093 \\
Methionine + Digestible Cystine, \% & 0.612 \\
Digestive Threonine, \% & 0.689 \\
Tryptophan Digestible, \% & 0.197 \\
Calcium \% & 0.768 \\
Available Phosphor, \% & 0.380 \\
\hline
\end{tabular}

${ }^{1}$ Warranty levels/ kg of product (1g of product / kg of feed): iron (55.0mg); Copper (11.0mg); Manganese (77.0mg); Zinc (71.5mg); Iodine (1.10mg). 2 Guarantee levels / kg product (0.5g of product / $\mathrm{kg}$ of feed): vit. A (6,000,000 IU); D3 (1.500.000 IU); E (15,000 IU); B1 (1.35); B2 (4g); B6 (2g); Pantothenic acid (9.35 g); Vit. K3 (1.5g); Nicotinic acid (20.0 g); Vit. B12 (20.0 g); Folic acid $(0.6 \mathrm{~g})$; Biotin $(0.08 \mathrm{~g})$.

Urine was collected daily in plastic buckets containing $20 \mathrm{~mL}$ of $1: 1 \mathrm{HCL}$ to avoid nitrogen volatilization and bacterial proliferation. A 10\% aliquot was conditioned daily in polyethylene terephthalate (PET) bottles and frozen at $-18^{\circ} \mathrm{C}$. Subsequently, these samples were homogenized and samples for the determination of crude energy were withdrawn.

All analyzes of food, feed and feces were performed following the procedures of Silva and Queiroz (2002). The dry matter digestibility coefficients (DMDC), organic matter (OMDC), neutral detergent fiber (NDFDC) and crude energy (CEDC) and crude energy metabolism coefficient (CEMC) were calculated according to Matterson et al. (1965).

Total carbohydrate (TC) contents were calculated according to the equations indicated by Sniffen et al. (1992) where TC $=100-(\%$ Crude Protein $+\%$ Ethereal Extract + Ash) and non-fibrous 
carbohydrate (NFC) contents by the formula $\mathrm{NFC}=$ TC - NDF.

The values of digestible (DE) and metabolizable energy (ME) were estimated by a regression analysis (ADEOLA, 2001) of DE and DM consumed (kcal $\mathrm{kg}^{-1}$ ) as a function of dehydrated cassava co-product consumption $(\mathrm{kg})$.

During the experimental period the mean air temperature of the metabolism room was taken in the center of the room at the level of the animals' loins with the aid of an analogue thermometer. The minimum temperature was recorded as $29 \pm 3.21^{\circ} \mathrm{C}$ and the maximum temperature $32 \pm 3.52^{\circ} \mathrm{C}$.

Experiment 2 - Performance test and blood parameters

Experiment 2 comprised of involved a total of 120 piglets (60 whole males and 60 females) with an initial live weight of $13.05 \pm 1.59 \mathrm{~kg}$, distributed in stalls in a randomized block design, with five treatments, replicated six times and with four animals per experimental unit. The animals' initial weight and the sex were used as a blocking factor. The animals were identified with numbered earrings and housed in suspended nursery stalls $\left(1.32 \mathrm{~m}^{2}\right)$, with polyethylene plastic floor, equipped with pacifier type drinking fountains and semi-automatic front feeders in masonry shed with concrete floors and ceramic roof tiles. Diets and water were provided ad libitum throughout the experimental period. A datalogger, with a capacity of 24 measurements/day, was used to measure the ambient temperature $\left({ }^{\circ} \mathrm{C}\right)$ and relative humidity of the experimental period. The minimum recorded temperature of the internal environment was $21 \pm 5.57^{\circ} \mathrm{C}$ with a maximum of $25 \pm 3.16^{\circ} \mathrm{C}$.

Treatments consisted of five feed a day with increasing inclusion levels $(0,3,6,9$ and 12\%) of the DCC. The feed, based on corn and soybean meal, were formulated to meet the recommendations of Rostagno et al. (2011), for barrows pigs of high genetic potential with superior performance, with live weight in the range of 15 to $30 \mathrm{~kg}$ (Table 2).

Table 2. Centesimal and nutritional composition of experimental feed with different levels of inclusion of dehydrated cassava co-product in pigs fed at initial stage (42 to 63 days of age).

\begin{tabular}{lccccc}
\hline \multirow{2}{*}{ Ingredients (\%) } & \multicolumn{5}{c}{ Levels of inclusion DCC (\%) } \\
\cline { 2 - 6 } & 0 & 3 & 6 & 9 & 12 \\
\hline Corn & 63.918 & 60.109 & 56.301 & 52.492 & 48.683 \\
Soybean meal (45\%) & 30.731 & 31.346 & 31.961 & 32.575 & 33.190 \\
Coproduto desidratado de mandioca & 0.00 & 3.000 & 6.000 & 9.000 & 12.000 \\
Soy oil & 1.541 & 1.545 & 1.588 & 1.814 & 2.039 \\
Monodicalcium phosphate & 1.138 & 1.363 & 1.550 & 1.555 & 1.560 \\
Limestone & 1.091 & 1.062 & 1.033 & 1.004 & 0.975 \\
Mineral and vitaminic premix ${ }^{1}$ & 0.500 & 0.500 & 0.500 & 0.500 & 0.500 \\
$\quad$ Common salt & 0.402 & 0.404 & 0.406 & 0.408 & 0.409 \\
Sulfato de lisina (50.7\%) & 0.402 & 0.391 & 0.379 & 0.368 & 0.357 \\
DL-methionine (98\%) & 0.136 & 0.140 & 0.144 & 0.148 & 0.152 \\
L-threonine (99\%) & 0.129 & 0.130 & 0.130 & 0.130 & 0.131 \\
L-triptofano (99\%) & 0.007 & 0.005 & 0.003 & 0.001 & 0.0002 \\
\hline Calculated Composition & & & & & \\
\hline EM (kcal kg-1) & 3.230 & 3.230 & 3.230 & 3.230 & 3.230 \\
Crude Protein (\%) & 19.500 & 19.500 & 19.500 & 19.500 & 19.500 \\
Digestive Lysine (\%) & 1.207 & 1.207 & 1.207 & 1.207 & 1.207
\end{tabular}

Continue... 
Continuation...

\begin{tabular}{lccccc} 
Digestive Threonine (\%) & 0.760 & 0.760 & 0.760 & 0.760 & 0.760 \\
Tryptophan Digestible (\%) & 0.217 & 0.217 & 0.207 & 0.207 & 0.207 \\
Met + Dig. Cys. (\%) & 0.676 & 0.676 & 0.676 & 0.676 & 0.676 \\
Calcium (\%) & 0.825 & 0.825 & 0.825 & 0.825 & 0.825 \\
Available Phosphor (\%) & 0.408 & 0.408 & 0.408 & 0.408 & 0.408 \\
Sodium (\%) & 0.200 & 0.200 & 0.200 & 0.200 & 0.200 \\
Neutral Detergent Fiber (NDF) (\%) & 13.240 & 13.640 & 14.040 & 14.440 & 14.840 \\
Ácid Detergent Fiber (ADF) (\%) & 7.360 & 7.670 & 7.970 & 8.280 & 8.580 \\
\hline
\end{tabular}

${ }^{1}$ Warranty levels / kg of product (5g of premix / kg of feed): folic acid (103.12mg); Pantothenic acid (2249.99mg); Biotin (16.88mg); Chlorohydroxyquinoline (15.00 g); Copper (22.07 g); Ethoxyquin (206.00mg); Iron (6733.40mg); Lysine (1 23.76 g); Manganese (1866.71mg); Methionine (110.25 g); Niacin (4687.50mg); Selenium (43.75mg); Threonine (46.64 g); Vit. A (1437500.00UI); Vit. B1 (224.96mg); Vit. B12 (2537.50mg); Vit. B2 (537.50mg); Vit. B6 (437.50mg); Vit. D3 (262500.00UI); Vit. E (4250.00 IU); Vit. K3 (375.00mg); Zinc (1000.00mg).

To verify the blood parameters, at the end of the initial phase period, two animals per experimental unit were selected, which remained fasting for eight hours. Blood samples were collected via cranial vena cava puncture in $4 \mathrm{~mL}$ test tubes containing urea anticoagulant (ethylenediaminetetraacetic acid-EDTA) and glucose (sodium fluoride), which were then sent to the Blood Parameters Laboratory of the Universidade Estadual do Oeste do Paraná. The samples were then centrifuged at 3,000 rpm for 15 minutes, with the plasma then collected and transferred to "Eppendorf" polyethylene tubes in duplicate, labelled and then stored in a freezer at $-5^{\circ} \mathrm{C}$ for further analysis. Plasma urea and glucose concentrations were performed with kits from Gold Analisa Diagnostica Ltd. The daily gain of weight $\left(\mathrm{DGW}, \mathrm{kg}\right.$ day $^{-1}$ ), daily feed intake (DFI, $\mathrm{kg}$ day ${ }^{-1}$ ) and feed conversion (FC, $\mathrm{kg} \mathrm{kg}^{-1}$ ) were evaluated for the performance analysis.

The normality of the experimental errors and the homogeneity of variances between the treatments for the several variables were previously evaluated using the Shapiro-Wilk and Levine tests, respectively. All parameters had normal distribution and homogeneity.

The effects of DCC levels on the dependent variables were verified using the $F$ test in the analysis of variance (ANOVA). When significant in ANOVA, the effect of DCC levels on the various variables was estimated using linear regression models. Five linear regression models were adjusted to the dependent variables data from DCC values $(0.01,3,6,9$ and $12 \%)$, according to the significance of the variation source in ANOVA, for model selection that best fits the average values of the characteristics. The adjusted linear regression models were represented by: First-order linear model: $\mathrm{y}_{\mathrm{i}}=\mathrm{b}_{0}+\mathrm{b}_{1} \mathrm{x}_{\mathrm{i}}+\varepsilon_{\mathrm{i} ;}$ Hyperbolic model: $\mathrm{y}_{\mathrm{i}}=\mathrm{b}_{0}+$ $\mathrm{b}_{1} / \mathrm{x}_{\mathrm{i}}+\varepsilon_{\mathrm{i} ;}$ Logarithmic model: $\mathrm{y}_{\mathrm{i}}=\mathrm{b}_{0}+\mathrm{b}_{1} \log _{10}\left(\mathrm{x}_{\mathrm{i}}\right)+$ $\varepsilon_{\mathrm{i}}$; Second-order linear model: $\mathrm{y}_{\mathrm{i}}=\mathrm{b}_{0}+\mathrm{b}_{1} \mathrm{x}_{\mathrm{i}}+\mathrm{b}_{2} \mathrm{x}_{\mathrm{i}}^{2}$ $+\varepsilon_{\mathrm{I}}$ and the Square root model: $\mathrm{y}_{\mathrm{i}}=\mathrm{b}_{0}+\mathrm{b}_{1} \mathrm{x}_{\mathrm{i}}+\mathrm{b}_{2} \mathrm{x}_{\mathrm{i}}$ $0.5+\varepsilon_{\mathrm{i}}$.

The ordinary least squares method was used to estimate the parameters of the regression models. The verification of the significance of each parameter was evaluated through the partial t-test, where the null hypothesis tested was $\mathrm{H}_{0}: \beta_{\mathrm{i}}=0$. The adherence of the models to the observed means of the characteristics was evaluated by observing the coefficient value of determination $\left(\mathrm{R}^{2}\right)$.

The averages contrasts of the characteristics between each level of DCC in relation to the reference treatment $(0 \%)$ were evaluated through the Dunnett's test. The level of significance $(\alpha)$ of 0.10 was adopted in all hypothesis tests. The analyses were performed using the $\mathrm{R}$ Development Core Team (TEAM, 2013). 


\section{Results and Discussion}

Experiment 1- Digestibility assay

The DCC's chemical and energy composition in the natural material (Table 3) showed that this food presents crude energy of $3,532 \mathrm{kcal} \mathrm{kg}^{-1}$, with $52.15 \%$ of starch and could be characterized as a high energy food and could be considered as an alternative swine feed in starting phase of the piglet's development.

In a dry basis, the dehydrated cassava co-product showed a crude energy value of $3,532 \mathrm{kcal} \mathrm{kg}^{-1}$, $10.35 \%$ lower than that of $3,960 \mathrm{kcal} \mathrm{kg}^{-1}$ of corn obtained by Rostagno et al. (2011). The values of integral cassava rasp described by Rostagno et al. (2011) and Embrapa (1991) were 3,631 kcal kg-1 and 3,614 $\mathrm{kcal} \mathrm{kg}^{-1}$, respectively, being higher than the CE of the DCC. However, the CE of the DCC was similar in comparison to the cassava root silage with inoculant obtained by Silva et al. (2008), with a CE value of $3,546 \mathrm{kcal} \mathrm{kg}^{-1}$.

Table 3. Chemical and energy composition of dehydrated cassava co-product in natural matter.

\begin{tabular}{lc}
\hline Chemical (\%) & \\
\hline Crude Energy (kcal kg-1) & 3532 \\
Dry Matter (\%) & 87.93 \\
Starch (\%) & 52.15 \\
Crude Protein (\%) & 1.06 \\
Neutral Detergent Fiber (\%) & 23.31 \\
Ácid Detergent Fiber (\%) & 15.43 \\
Lignin (\%) & 3.60 \\
Hemicelulose (\%) & 7.88 \\
Celulose (\%) & 14.65 \\
Calcium (\%) & 0.12 \\
Magnesium (\%) & 0.02 \\
Ethereal Extract (\%) & 0.32 \\
Ashes (\%) & 1.57 \\
Total Carbohydrates (\%) & 97.05 \\
Non Fibrous Carbohydrates (\%) & 73.74 \\
\hline
\end{tabular}

For CP, DCC presented a value of $1.06 \%$ (Table 3), this value was considered inferior when compared to the integral cassava scrap, which according to Rostagno et al. (2011) was $2.48 \%$. The protein content in the food may vary due to the different factors, such as, plant variety and the type of processing by which it was submitted, which results in different values of cassava's CP (EMMANUEL et al., 2012).

In addition, it presented a fibrous food with 23.31\% NDF and $15.43 \%$ ADF (Table 3), values higher than corn, $12.06 \% \mathrm{NDF}$ and $3.39 \% \mathrm{ADF}$, and of the whole cassava scrap, $11.78 \%$ of NDF and $4.28 \%$ of ADF, (ROSTAGNO et al., 2011). The ADF value of DCC was similar to that found by Aquino et al. (2014), who worked with whole bran of parboiled rice in the diets of piglets, presenting NDF values of 33.75 and ADF of $15.91 \%$, and can be used in piglet feeding in up to $16 \%$.

The DCC presented the content of $0.32 \% \mathrm{EE}$, being superior to that presented by Silva et al. (2008), who worked with cassava root silage without additives $(0.24 \%)$ and with inoculant $(0.22 \%)$, and lower than that described by Rostagno et al. (2011) for integral cassava scrap $(0.59 \%)$. 
The results of the apparent digestibility coefficients (ADC), metabolism coefficient (MC) of the crude energy and digestible nutrients (Table 4) of the dehydrated cassava co-product in starting piglets feeding showed that DMDC values (74.52 $\%)$ and OMDC (91.14\%) were higher than those described by Carvalho et al. (2009), who worked with mellow coffee husks, fibrous food similar to DCC and obtained DMDC values of $62.64 \%$ and OMDC of $67.87 \%$. However, they were lower than the values obtained by Silva et al. (2008), using cassava root silage without inoculant, with a DMDC of $92.57 \%$ and DCC of $90.04 \%$.

The digestibility coefficients verified for the DCC were $78.95 \%$ for CE, $75.13 \%$ for NDF, $47.18 \%$ for $\mathrm{ADF}$, and $78.22 \%$ for the crude energy metabolism coefficient (CEMC) (Table 4). These results were superior to those described by Carvalho et al. (2009), who observed values for CEDC of $63.06 \%$, NDFDC of $50.64 \%$, and of CEMC of $58.60 \%$, and lower for ADFDC with 55.71\%.

Table 4. Coefficients of apparent digestibility (CAD), metabolisation coefficients (MC) of crude energy and digestible nutrients (expressed in natural matter) of the dehydrated cassava co-product in piglet feeding in starting phase.

\begin{tabular}{ll}
\hline Dibestibility coeffcients, \% & \\
\hline Dry Matter of CAD & 74.52 \\
Organic Matter of CAD & 91.14 \\
Fiber in Neutral Detergent of CAD & 75.13 \\
Fiber in Acid Detergent of CAD & 47.18 \\
Crude Energy of CAD & 78.95 \\
Crude Energy of MC & 78.22 \\
\hline Digestible Nutrients & \\
\hline Digestible dry matter, \% & 65.53 \\
Organic matter digestible, \% & 78.13 \\
Fiber in neutral detergent, \% & 17.51 \\
Fiber in acid detergent, \% & 11.00 \\
Digestible Energy, kcal kg-1 & 3022 \\
Metabolizable Energy, kcal kg-1 & 2984 \\
ME:DE & 0.987 \\
\hline
\end{tabular}

The values of digestible and metabolizable energy, respectively, were lower than whole cassava rasp $\left(3,048\right.$ and 3,020 $\left.\mathrm{kcal} \mathrm{kg}^{-1}\right)$ (ROSTAGNO et al., 2011).

In order to obtain the DE and MS of the DCC, the slope of the linear relationship between DE and DM consumption was estimated (Pictures 1 and 2), showing that this co-product shows similar ME to corn $\left(3,460\right.$ and $\left.3,340 \mathrm{kcal} \mathrm{kg}^{-1}\right)$.

The results obtained from DE and ME of the DCC were inferior when compared to the research done by Silva et al. (2008) who used cassava root silage in starting piglets feeding and obtained DE of 3,249 kcal kg-1 and 3,271 kcal kg-1. However, the DCC showed higher energy values in relation to the research done by Carvalho et al. (2009), using mellow coffee husk $(\mathrm{MCH})$ in swine feed in starting phase, in which they obtained values of 2,352 and $2,186 \mathrm{kcal} \mathrm{kg}^{-1}$, respectively, for DE and DM.

The DE and ME values obtained in the present research, in which piglets were fed DCC, suggest that the fibrous fraction (NDF, ADF) contained in this co-product was not a limiting factor for nutrient and energy digestibility, since they were high. These results are relevant because dietary fiber may influence nutrient and energy digestibility, either 
by the soluble or insoluble type, by the proportion used by the animal and the stage in which it is found (GENOVA et al., 2016).

Experiment 2 - Performance test and blood parameters

The final body weight (FBW), mean daily feed intake (DFI), daily gain of weight (DGW) and feed conversion (FC) results of piglets fed with and without inclusion of DCC (Table 5) show that there was no significant effect $(\mathrm{p}>0.10)$ of DCC levels on the final body weight and on daily gain of weight, however, there was a significant effect $(\mathrm{p}<$ 0.10 ) of DCC levels on daily feed intake and feed conversion.
The mean value of FC of swine fed with feed containing $3 \%$ of DCC was 1.55 , which differed (p $<0.10)$ from the mean $\mathrm{FC}$ value of the piglets that received free feed $(0 \%)$ of DCC $(1,461)$ (Table 5$)$. This result indicated that despite the mean values of DFI and DGW, the treatments of 3, 6, 9 and 12 $\%$ were similar to the reference treatment and the control diet performed best when compared to FC in relation to the $3 \%$ level. The difference found between the results can be related to the dietary fiber content in DCC, since a reduction in feed nutrient utilization are commonly found impairing the gain of weight and feed conversion (HEDEMANN et al., 2006), it also may have a reduction or increase in the feed intake depending on the level and type of fiber presented (YU et al., 2016).

Table 5. Observed mean values of performance characteristics of pigs in starting phase, according to the dehydrated cassava co-product levels used in the reference diet $(0 \%)$, at a $10 \%$ probability level.

\begin{tabular}{|c|c|c|c|c|c|c|c|c|}
\hline \multirow{2}{*}{ Variable } & \multicolumn{5}{|c|}{ Levels of inclusion of DCC $\%$} & \multirow{2}{*}{ Average } & \multirow{2}{*}{$\mathrm{CV}^{1}$} & \multirow{2}{*}{$\operatorname{Reg}^{2}$} \\
\hline & 0 & 3 & 6 & 9 & 12 & & & \\
\hline $\mathrm{IW}^{3}, \mathrm{~kg}$ & 13.08 & 12.82 & 13.04 & 13.12 & 12.98 & 13.01 & 7.65 & NS \\
\hline $\mathrm{FBW}^{4}, \mathrm{~kg}$ & 27.00 & 26.62 & 26.88 & 26.60 & 26.16 & 26.65 & 2.45 & NS \\
\hline $\mathrm{DFI}^{5}, \mathrm{~kg}$ & 1.09 & 1.16 & 1.13 & 1.11 & 1.07 & 1.11 & 4.60 & MRQ \\
\hline $\mathrm{DGW}^{6}, \mathrm{~kg}$ & 0.75 & 0.75 & 0.75 & 0.73 & 0.71 & 0.74 & 4.85 & NS \\
\hline $\mathrm{FC}^{7}$ & 1.46 & $1.55^{*}$ & 1.51 & 1.52 & 1.50 & 1.50 & 3.58 & $\mathrm{MH}$ \\
\hline
\end{tabular}

${ }^{1} \mathrm{CV}=$ Coefficient of variation; 2 Regression analysis: NS = Not significant; SRM = Square Root Model; HM = Hyperbolic Model; Means followed by asterisks, in the line, differ from the treatment; ${ }^{3} \mathrm{IW}=$ Initial weight; ${ }^{4} \mathrm{FBW}=$ Final body weight; ${ }^{5} \mathrm{DFI}=\mathrm{daily}$ feed intake; ${ }^{6} \mathrm{DGW}=$ daily gain of weight; $\mathrm{FC}=$ feed conversion.

The regression models that best fit the observed means of the performance characteristics were: $y$ $=1,087-0.025 \mathrm{x}+0.080 \mathrm{x}^{0.5}(\mathrm{DFI})$ and $\mathrm{y}=1,522-$ $0.00060 / \mathrm{x}$ (FC). The determination coefficient of the models was $\mathrm{R}^{2}=97.35 \%(\mathrm{DFI})$ and $\mathrm{R}^{2}=68.44$ $\%$ (FC) (Picture 3).

The fit quality of the hyperbolic model to the observed FC data was intermediate to high, explaining almost $70 \%$ of the data variation. The estimated FC value when using the $0.01 \%$ DCC level in the diet was 1.46. The estimates of FC, based on the predictive model and when using DCC levels in the $0.5 \%, 1.0 \%$ and $3.0 \%$ feed were $1.52 \%$.
This can be verified by observing the Dunnett test result, applied in the contrast of averages between $0 \%$ and $3 \%$ of DCC (Table 5), whose observed value of FC (1.55) for the $3 \%$ treatment of DCC was significantly different $(\mathrm{P}<0.10)$ to the $\mathrm{FC}$ value (1.46) for the reference treatment $(0 \%$ DCC). The increasing levels of DCC in feed may have increased the viscosity of the gastrointestinal content, concomitantly reducing the passage of digest, increased satiety and decreased intake.

It can be observed that, based on the predictive model of FC, that from the level of $0.01 \%$ of DCC, the means do not differ, suggesting a similarity 
between estimated values of $\mathrm{FC}$ for pigs fed with higher levels (greater than $0.1 \%$ ), of DCC. These findings can be attributed to the higher levels of neutral detergent fiber and acid detergent fiber of the DCC in relation to corn (Table 5), which interfere with the digestion and absorption processes of nutrients, mainly starch. However, the supply of fiber-containing foods in the animals diets after weaning may lead to an improvement in the intestinal health of piglets (WILLIAMS et al., 2001), since depending on the amount and source of dietary fiber, there may be an increase in the intestine oxidative metabolism capacity and a better distribution of energy metabolites (WEBER; KERR, 2012).

The results obtained in the present study were different when compared to Silva et al. (2008), who used cassava root silage for piglets in starting phase with or without whole soybeans. It can be observed an improvement in the animals FC that received diet with cassava root silage without additives in relation to those that received diets of cassava root silage with whole soybean or reference feed.

The FBW and DFI variables were uniform, since no significance was obtained for the parameters. The mean values of FBW and DGW were 26.64 and $0.737 \mathrm{~kg}$, respectively, for any levels of DCC used instead of corn. This can also be seen in the results (Table 5), where there was no difference (P $>0.10$ ) between observed means of the treatments containing DCC levels in relation to treatment without DCC (0 \%).

The results suggested that any level of DCC used in diets does not alter the mean values of FBW and DGW, and technical and economic criteria should be followed for the choice of ingredients and inclusion levels in formulating swine feed at an early stage. In similar research, Gomez (1991) used whole cassava rasp $(0,20$ and 40\%) in starting piglets feeding, and found no difference for mean daily consumption between treatments.

In another paper, Moreira et al. (2009) used soybean hulls with or without enzyme complex, and it was observed that with the addition of 15 $\%$ of soybean hulls in piglet feeding, there was a decrease in DFI, regardless of the amount of enzyme complex. For DGW, the animals that consumed the diet without the presence of soybean hull did not present a difference as a function of the levels of enzyme complex added to the feed.

The DCC was presented with a fibrous food and, although it was supplied at increasing levels for the piglets, no significant difference was observed for the DGW parameter. This was different from Hermes et al. (2009), whom suggests that the supply of 7\% of NDF in piglets can lead to higher productive performance. Scholten et al. (2002) used fermented wheat in liquid diets for recently weaned piglets and observed that this food can interfere in the gastrointestinal tract in a positive way, preventing unpleasant changes in the piglets' mucosa.

Mean FBW values of the animals were not altered, indicating that the inclusion of a cassava coproduct (DCC) at increasing levels in the piglet feed did not negatively affect performance. Molist et al. (2009), using wheat bran and beet pulp, provided either separately or together, observed that after 10 days of weaning the animals, the contained wheat bran in their feed presented higher feed intake than those that did not receive fiber, however there were differences in the parameters of DGW and FC.

In this study, it was observed that the DCC besides energetic is fibrous and its supply at increasing levels of inclusion in the diets of piglets in the initial stage did not change and the animals' performance. However, the study by Högberg and Lindberg (2004), using different types of fibers (triticale, wheat, oats and barley) in starting piglets feeding, found that there was an increase in the animals weight gain, suggesting that this increase would be related to the internal organs gain of weight.

In another experiment, done by Gomes et al. (2012), the authors included up to $30 \%$ rice bran in 
pigs fed from 43 to 67 days of age, and there was no negative effect on the animal's performance.

For the blood parameters analysis, the results showed that there was no effect $(\mathrm{P}>0.10)$ of DCC levels on glucose and blood urea in the different treatments (Table 6). The concentration of glucose and urea $\left(\mu \mathrm{g} \mathrm{mL}^{-1}\right)$ in the blood plasma of piglets was 69.14 and 23.12, respectively, for the starting phase.
These results differed from those obtained by Adesehinwa (2009), who evaluated the concentration of urea and glucose in the blood serum with the replacement of corn by palm kernel meal (PKM) supplemented with two levels of cassava residual meal (CRM), PKM + $10 \%$ CRM and PKM $+20 \%$ CRM, and obtained a mean of urea of 41.25 and 44.13 and glucose of 84.13 and 90.13 , respectively. The author also states that the blood test to determine the state of the animals' health is of great importance.

Table 6. Observed mean values of glucose and blood urea $(\mu \mathrm{g} / \mathrm{mL})$ at the end of the starting phase, according to the dehydrated cassava co-product levels.

\begin{tabular}{|c|c|c|c|c|c|c|c|c|}
\hline \multirow{2}{*}{$\underline{\text { Parameter }}$} & \multicolumn{5}{|c|}{ Levels of inclusion of DCC $\%$} & \multirow{2}{*}{$\underline{\text { Average }}$} & \multirow{2}{*}{$\mathrm{CV}(\%)^{1}$} & \multirow{2}{*}{$\mathrm{Reg}^{2}$} \\
\hline & 0 & 3 & 6 & 9 & 12 & & & \\
\hline Glucose & 68.4 & 72.2 & 65.8 & 63.8 & 75.5 & 69.14 & 25.2 & NS \\
\hline Urea & 22.5 & 23.0 & 25.1 & 22.1 & 22.9 & 23.12 & 21.4 & NS \\
\hline
\end{tabular}

Averages do not differ in the same line, at a 10\% probability level; Mean residual square: 303.91 (glucose) and 24.46 (urea). ${ }^{1}$ Coefficient of variation; ${ }^{2}$ Regression analysis: NS $=$ Not significant.

The plasma nitrogen evaluation shows the adequate supply of amino acids in the diet, depending on both the quality and the quantity in its supply (COMA et al., 1995). The urea nitrogen is a good parameter to show that dietary amino acids have been used by pigs (FRAGA et al., 2008), and the concentration of urea in the blood can tell the nutritional condition of the animal, as well as quality of the protein that was provided (WEI; ZIMMERMAN, 2003).

Glucose is the most important metabolite for respiratory oxidation, with great importance for vital functions such as brain metabolism. The amount of glucose in the blood is important to indicate diseases such as ketoses. Due to the homeostatic mechanisms, which are quite efficient, the blood glucose content doesn't very much. Thus, the glycemic level does not have a direct effect of diet due to homeostatic mechanisms, except for animals with advanced malnutrition (GONZÁLEZ; SCHEFFER, 2002).

\section{Conclusion}

The use of dehydrated cassava co-product can be an energetic alternative in piglet feed. The performance evaluated by final body weight, daily feed intake and daily gain of weight is not influenced by the dehydrated cassava co-product inclusion, and it can be used up to $12 \%$ in swine feed in starting phase without negative consequences on the piglet.

\section{Thanks}

To Capes for the financing of the scholarship and Copagril (Cooperativa Agroindustrial de Marechal Cândido Rondon), by the partner in the research realization.

\section{References}

ADEOLA, O. Digestion and balance techniques in pigs. In: LEWIS, A. J.; SOUTHERN, L. L. (Ed.). Swine nutrition. 2. ed. Washington: CRC Press, 2001. p. 903-916. 
ADESEHINWA, A. O. K. Palm kernel cake supplemented with cassava flour waste as energy source for pigs. Revista Brasileira de Ciências Agrárias, Recife, v. 4, n. 4, p. 479-484, 2009.

ALBUQUERQUE, D. M. N.; LOPES, J. B.; KLEIN JUNIOR, M. H.; MERVAL, R. R.; SILVA, F. E. S.; TEIXEIRA, M. P. F. Resíduo desidratado de cervejaria para suínos em terminação. Arquivo Brasileiro de Medicina Veterinária e Zootecnia, Belo Horizonte, v. 63, n. 2, p. 465-472, 2011.

AQUINO, T. M.; WATANABE, P. H.; CARVALHO, L. E.; FREITAS, E. R.; NEPOMUCENO, R. C.; OLIVEIRA, E. L.; AGUIAR, G. C. Níveis de inclusão do farelo de arroz parboilizado em rações para leitões na fase de creche. Arquivo Brasileiro de Medicina Veterinária e Zootecnia, Belo Horizonte, v. 66, n. 5, p. 1531-1538, 2014.

ASSOCIATION OF OFFICIAL ANALYTICAL CHEMISTS - AOAC. Official methods of analysis. 16. ed. Arlington: AOAC Internacional, 1990. 1025 p.

CARVALHO, P. L. O.; MOREIRA, I.; PAIANO, D.; MOURINHO, F. L.; OLIVEIRA, G. C. de; KURODA JUNIOR, I. S. Casca de café melosa ensilada na alimentação de suínos na fase inicial. Ciência Agrotecnologia, Lavras, v. 33 n. 5, p. 1400-1407, 2009.

COMA, J.; CARRION, D.; ZIMMERMAN, D. R. Use of plasma urea nitrogen as a rapid response criterion to determine the lysine requirement of pigs. Journal of Animal Science, Champaign, v. 73, n. 2, p. 472-481, 1995.

EMMANUEL, O. A.; CLEMENT, A.; AGNES, S. B.; CHIWONA-KARLTUN, L.; DRINAH, B. N. Chemical composition and cyanogenic potential of traditional and high yielding CMD resistant cassava (Manihot esculenta Crantz) varieties. International Food Research Journal, Serdang, v. 19, n. 1, p. 175-181, 2012.

EMPRESA BRASILEIRA DE PESQUISA E AGROPECUÁRIA - EMBRAPA. Tabela de composição química e valores energéticos de alimentos para suínos e aves. 3. ed. Concórdia: EMBRAPA - Centro Nacional de Pesquisa de Suínos e Aves, 1991. 97 p.

FERREIRA, A. H. C.; LOPES, J. B.; ABREU, M. L. T.; SANTANA JÚNIOR, H. A. D.; ARAÚJO, F. S.; SARAIVA, A. Whole scrapings of cassava root in diets for broilers from 1 to 21 days of age. Acta Scientiarum Animal Sciences, Maringá, v. 36, n. 4, p. 357-362, 2014.

FIORDA, F. A.; SOARES JÚNIOR, M.; SILVA, F. A.; SOUTO, L. R. F.; GROSSMANN, M. V. E. Farinha de bagaço de mandioca: aproveitamento de subproduto e comparação com fécula de mandioca. Pesquisa
Agropecuária Tropical, Goiânia, v. 43, n. 4, p. 408-416, 2013.

FRAGA，A. L.; MOREIRA, I.; FURLAN, A. C.; BASTOS, A. O.; OLIVEIRA, R. P. D.; MURAKAMI, A. E. Lysine requeriment of starting barrows from two genetic groups fed on low crude protein diets. Brazilian Archives of Biology and Technology, Curitiba, v. 51, n. 1, p. 49-56, 2008.

GENOVA, J. L.; CASTRO, D. E. S. E.; CARDOSO, A. T.; PIRES FILHO, I. C.; CHAMBO, P. C. S. Papel das fibras em dietas para leitões. Nutritime, Viçosa, MG, v. 13, n. 2, p. 4615-4620, mar. 2016.

GOMES, T. R.; CARVALHO, L. E.; FREITAS, E. R.; NEPOMUCENO, R. C.; ElleRY, E. A. C.; MOREIRA, R. H. R. Farelo de arroz integral em rações para leitões de 43 a 67 dias de idade. Ciência Animal Brasileira, Goiânia, v. 13, n. 2, p. 189-196, 2012.

GOMEZ, G. G. Use of cassava products in pig feeding. Pig News and Information, Wallingford, v. 3, n. 12, p. 387-390, 1991.

GONZÁlEZ, F. H. D.; SCHEFFER, J. F. S. Perfil sanguíneo: ferramenta de análise clínica, metabólica e nutricional. In: CONGRESSO NACIONAL DE MEDICINA VETERINÁRIA, 2002, Gramado. Anais... Porto Alegre: SBMV/SOVERGS, 2002. p. 5-17.

HEDEMANN, M. S.; ESKILDSEN, M.; LÆRKE, H. N.; PEDERSEN, C.; LINDBERG, J. E.; LAURINEN, P.; KNUDSEN, K. E. Intestinal morphology and enzymatic activity in newly weaned pigs fed contrasting fiber concentrations and fiber properties. Journal of Animal Science, Champaign, v. 84, n. 6, p. 1375-1386, 2006.

HERMES, R. G.; MOLIST, F.; YWAZAKI, M.; NOFRARÍAS, M.; GOMEZ DE SEGURA, A.; GASA, J.; PÉREZ, J. F. Effect of dietary level of protein and fiber on the productive performance and health status of piglets. Journal of Animal Science, Champaign, v. 87, n. 11, p. 3569-3577, 2009.

HÖGBERG, A.; LINDBERG, J. E. Influence of cereal non-starch polysaccharides and enzyme supplementation on digestion site and gut environment in weaned piglets. Animal Feed Science and Technology, Amsterdam, v. 116, n. 1-2, p. 113-128, 2004.

MATTERSON, L. D.; POTTER, L. M.; STUTZ, M. W.; SINGSEN, E. P. The metabolizable energy offeed ingredients for chickens. Research Report Connecticut Agricultural Experiment Station, New Haven, v. 7, n. 1, p. 11-14, 1965.

MOLIST, F.; SEGURA, A. G.; GASA, J.; HERMES, R. G.; MANZANILLA, E. G.; ANGUITA, M.; PÉREZ, J. 
F. Effects of the insoluble and soluble dietary fibre on the physicochemical properties of digesta and the microbial activity in early weaned piglets. Animal Feed Science and Technology, Amsterdam, v. 149, n. 3-4, p. 346-353, 2009.

MOREIRA, I.; MOURINHO, F. L.; CARVALHO, P. L. O.; PAIANO, D. Avaliação nutricional da casca de soja com ou sem complexo enzimático na alimentação de leitões na fase inicial. Revista Brasileira de Zootecnia, Viçosa, MG, v. 38, n. 12, p. 2408-2416, 2009.

PEKAS, J. C. Versatible swine labotarory apparatus for physiologic and metabolic studies. Journal of Animal Science, Champaign, v. 27, n. 5, p. 1303-1306, 1968.

PICOLI, K. P.; MURAKAMI, A. E.; NUNES, R. V.; DUARTE, C. R. A.; EYNG, C.; OSPINA-ROJAS, I. C. Cassava starch factory residues in the diet of slow-growing broilers. Tropical Animal Health and Production, Modlothian, v. 46, n. 8, p. 1371-1381, 2014.

ROSTAGNO, H. S.; ALBINO, L. F. T.; DONZELE, J. L.; GOMES, P. C.; OLIVEIRA, R. F.; LOPES, D. C.; FERREIRA, A. S.; BARRETO, S. L. T. Tabelas brasileiras para aves e suínos: composição de alimentos e exigências nutricionais. 3. ed. Viçosa, MG: Universidade Federal de Viçosa, 2011. 252 p.

SAKOMURA, N. K.; ROSTAGNO, H. S. Métodos de pesquisa em nutrição de monogástricos. Jaboticabal: FUNEP, 2016. 262 p.

SCHOLTEN, R. H. J.; VAN DER PEET-SCHWERING, C. D.; DEN HARTOG, L. A.; BALK, M.; SCHRAMA, J. W.; VERSTEGEN, M. W. A. Fermented wheat in liquid diets: effects on gastrointestinal characteristics in weanling piglets. Journal of Animal Science, Champaign, v. 80 , n. 5, p. 1179-1186, 2002.

SILVA, D. J.; QUEIROZ, A. C. Análise de alimentos: métodos químicos e biológicos. 3. ed. Viçosa, MG: UFV, 2002. 235 p.

SIlVA, M. A. A.; FURLAN, A. C.; MOREIRA, I.; PAIANO, D.; SCHERER, C.; MARTINS, E. N. Avaliação nutricional da silagem de raiz de mandioca contendo soja integral para leitões na fase inicial. Revista Brasileira de Zootecnia, Viçosa, MG, v. 37, n. 8, p. 14411449, 2008.

SNIFFEN, C. J.; O'CONNOR, J. D.; VAN SOEST, P. J.; FOX, D. G.; RUSSELL, J. B. A net carbohydrate and protein system for evaluating cattle diets: II. Carboihydrate and protein availability. Journal of Animal Science, Champaign, v. 70, n. 10, p. 3562-3577, 1992.

SOUSA, J. P. L.; RODRIGUES, K. F.; ALBINO, L. F. T.; SANTOS NETA, E. R. D.; VAZ, R. G. M. V.; PARENTE, I. P.; AMORIM, A. F. Bagaço de mandioca em dietas de frangos de corte. Revista Brasileira de Saúde e Produção Animal, Salvador, v. 13, n. 4, p. 10441053, 2012.

TEAM, R. C. $R$ : a language and environment for statistical computing. R Foundation for Statistical Computing. Vienna, Austria: The R Foundation For Statistical Computing, 2013. Available at: <http://www.R-project. org/>. Accessed at: 20 apr. 2016.

WEBER, T. E.; KERR, B. J. Metabolic effects of dietary sugar beet pulp or wheat bran in growing female pigs. Journal of Animal Science, Champaign, v. 90, n. 2, p. 523-532, 2012.

WEI, R.; ZIMMERMAN, D. R. An evaluation of the NRC (1998) growth model in estimating lysine requirements of barrows with a lean growth rate of 348 g/d. Journal of Animal Science, Champaign, v. 81, n. 7, p. 1772-1780, 2003.

WILLIAMS, B. A.; VERSTEGEN, M. W. A.; TAMMINGA, S. Fermentation in the large intestine of single-stomached animals and its relationship to animal health. Nutrition Research Review, Cambridge, v. 14, n. 2, p. 207-227, 2001.

YU, C.; ZHANG, S.; YANG, Q.; PENG, Q.; ZHU, J.; ZENG, X.; QIAO, S. Effect of high fibre diets formulated with different fibrous ingredients on performance, nutrient digestibility and faecal microbiota of weaned piglets. Archives of Animal Nutrition, Berlin, v. 70, n. 3, p. 263-277, 2016. 
